\title{
CoA Synthase influences adherence-independent growth and survival of mammalian cells in vitro
}

\author{
O. S. Breus ${ }^{1}$, I. O. Nemazanyy ${ }^{1}$, I. T. Gout ${ }^{1,2}$, V.V Filonenko', G. G. Panasyuk ${ }^{1}$ \\ ${ }^{1}$ Institute of Molecular Biology and Genetics National Academy of Sciences of Ukraine \\ 150, Zabolotnogo Str., Kyiv 03680, Ukraine \\ ${ }^{2}$ Research Department of Structural and Molecular Biology, University College London \\ Gower Str., London WC1E 6BT, UK \\ v.v.filonenko@imbg.org.ua
}

\begin{abstract}
Aims. We aimed to study the influence of the expression level, activity and subcellular localization of CoA Synthase (CoASy) on anchoring independent growth and viability of in vitro cultured cells. Methods. Abilities of cells to form colonies in semisolid agarose and survive in growth factor depleted conditions were tested. A panel of HEK293 stable cell lines which over express wild type, catalytically inactive or mitochondria association mutants of CoASy were used in the study. Effects of CoASy down regulation by siRNA on malignant phenotype of HepG2 cells have been studied. Results. We report here that changes in CoASy expression level affect anchoring independent growth and viability of mammalian cells. Catalytic activity of CoASy and its association with mitochondria are crucial for mediating of the observed effects. Conclusions. Presented data indicate CoASy has positive impact on activity of signalling pathways in the cell and reveal unknown before functional link between signal transduction and metabolism.
\end{abstract}

Keywords: CoA Synthase, coenzyme A, anchoring independent growth, cells viability.

Introduction. CoA Synthase (CoASy) is mitochondria associated enzyme which facilitates the last two catalytic steps of de novo CoA biosynthesis in mammalian cells $[1,2]$. The final product of CoASy enzymatic activity - CoA is ubiquitous carrier of activated acyl moieties that is indispensable for the metabolism of carbohydrates and lipids [3, 4]. Nevertheless, functions of coenzyme $\mathrm{A}$ and its derivatives are not restricted by metabolism. They also are involved in regulatory cellular processes [4]. Well established example is acylation of proteins which is a fundamental regulatory mechanism utilized by cells to modulate variety of cellular processes including gene

(C) Institute of Molecular Biology and Genetics NAS of Ukraine, 2009 transcription $[5,6]$, signal transduction $[7,8]$ and membrane trafficking [9]. Genetic analysis of Drosophila melanogaster with hypomorphic mutant alleles corresponding to one of the three CoA synthesizing enzymes (PANK; PPCS; PPAT/PPCK) revealed that $\mathrm{CoA}$ plays important roles in lipid biosynthesis, cell protection from oxidative stress, maintenance of DNA integrity, cell proliferation and organogenesis [10]. Recently, we found that CoASy form complexes with a number of signaling proteins in mammalian cells. Its interaction with kinase of S6 ribosomal protein (S6K) [11], p85 $\alpha$ regulatory subunit of PI3K [12], Shp2 protein tyrosine phosphatase (unpublished observation) and signaling proteins Shc (unpublished observation) were revealed. Moreover, 
we found that siRNA mediated knock down of CoASy level in HEK293 cells led to a decrease in activity of Akt1, PDK Ser/Tre kinases and also tyrosine kinases in a dose dependent manner [12].

In this study, we report that changes in expression level of CoA Synthase influence the ability of adherent cells to survive and proliferate without contacts with extracellular matrix and also to survive in conditions of growth factors deprivation. Catalytic activity and subcellular localization of CoASy are essential for the observed phenotype. Presented data together with earlier observations [12] demonstrate positive impact CoASy has on activity of signalling pathways in the cell and reveal unknown before functional link between signal transduction and metabolism.

Materials and Methods. Antibodies and reagents. The production of anti-CoASy (C-terminus) antibody was described previously [1]. Anti-Myc (9E10) antibody was from Santa Cruz (Santa Cruz, USA). Anti-tubulin antibody was purchased from Cell Signalling (Cell Signalling, USA). The expressing vectors pcDNA3.1 CoASy-Myc wt, pcDNA3.1 CoASy-Myc H203A/G400A and pcDNA3.1 CoASyMyc $\triangle \mathrm{TM}$ were generated and described previously $[11,13]$. The CoASy and scrambled siRNAs were obtained from MWG Biotech, Germany. siRNA duplexes were transfected into HepG2 cells using INTERFERin $^{\mathrm{TM}}$ (Polyplus Transfection, France).

Cell lines and culture. Human embryonic kidney 293 and human hepatocellular carcinoma, HepG2 cells were from the American Type Culture Collection (Manassass, VA), and maintained in Dulbecco's modified Eagle's medium supplemented with $10 \%$ fetal bovine serum, $100 \mathrm{U} / \mathrm{ml}$ of penicillin, and $100 \mu \mathrm{g} / \mathrm{ml}$ of streptomycin. HEK293 cell lines stably overexpressing Myc-CoASy, Myc-H203A/G400ACoASy, $\triangle \mathrm{TMCoASy}$ proteins were established by transfection of linearized by MunI (Fermentas, Lithuania) $p c D N A 3.1$ based vectors or $p E G F P-C 1$ plasmid. For transfections JetPEI (Polyplus Transfection, France) reagent was used according to manufacturer's recommendations. Stably transformed cells were selected on the standard growth medium supplemented with $800 \mu \mathrm{g} / \mathrm{ml}$ of G418 (Invitrogene, USA). For CoASy knock down, HepG2 cells were transfected with 200 pmol of CoASy siRNA or scrambled siRNA with INTERFERin ${ }^{\mathrm{TM}}$ according to manufacturer's recommendations and $48 \mathrm{hrs}$ after transfection subjected to the analysis by immunoblotting and plated in semisolid agarose as described further.

Extracts preparation and immunoblottings. Cells were lysed with buffer containing $10 \mathrm{mM}$ Tris, $\mathrm{pH}$ 7.5, $150 \mathrm{mM} \mathrm{NaCl}, 5 \mathrm{mM}$ EDTA, $5 \mathrm{mM}$ sodium fluoride, $1 \%$ Triton $\mathrm{X}-100,1 \mathrm{mM} \mathrm{Na} \mathrm{VO}_{4}$ and a mixture of protease inhibitors (Roche Applied Science, France). Whole extracts were centrifuged at $10000 \mathrm{~g}$ for $20 \mathrm{~min}$ at $4{ }^{\circ} \mathrm{C}$. Immunoblotting was performed as described previously [1]. The antigen-antibody complexes were detected with ECL system (Millipore, USA). When membranes had to be re-probed, they were stripped, reblocked and re-probed with other primary antibodies.

Trypan blue exclusion and colonies-forming assays. The viability of generated HEK293 stable cell lines was analysed in trypan blue exclusion assay. Cells were resuspended in PBS $48 \mathrm{hrs}$ post the initiation of serum starvation. The portion of cells was thereafter diluted $1: 5$ with $0.4 \%$ trypan blue (Sigma, USA) and scored under light microscopy. Viable (unstained) and nonviable (blue-stained) cells were counted. The ratio of total/dead cells was calculated and folds over EGFP overexpressing cell line were presented as a graph. The results are presented as the mean $\pm \mathrm{s}$. d. of 5 independent experiments, with $\mathrm{p} \leq 0.05$, a minimum of 200 cells being scored in each experiment.

To monitor the capacity of CoASy stable cell lines to grow in semi-solid medium in vitro, cells were transferred into $2 \mathrm{ml}$ of complete DMEM containing $0.7 \%$ low-melting agarose. $10^{3}$ cells were seeded into $35 \mathrm{~mm}$ dishes containing a $2 \mathrm{ml}$ layer of solidified $1.2 \%$ low-melting agarose in complete medium. Colonies were stained 3 weeks later with MTT and counted using Quantity One Software (Bio-Rad, USA). The folds over control (EGFP overexpressing cells) are presented as the mean $\pm \mathrm{s}$. d. of 5 independent experiments, with $\mathrm{p} \leq 0.05$.

Results and Discussion. CoASy promotes cell survival. Normal differentiated cells require growth factors, hormones and contacts with extracellular matrix molecules to sustain their viability in vitro and in vivo [14-17]. It was described in multiple studies that PI3K-Akt and Ras-Raf-MAPK1/2 signalling pathways are the key players in transduction of survival signals 
$A$

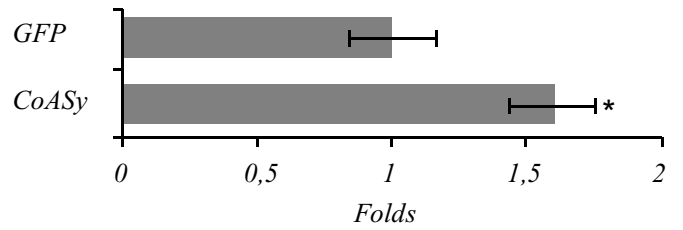

$B$

GFP CoASy CoASy203/400 ? TMCoASy

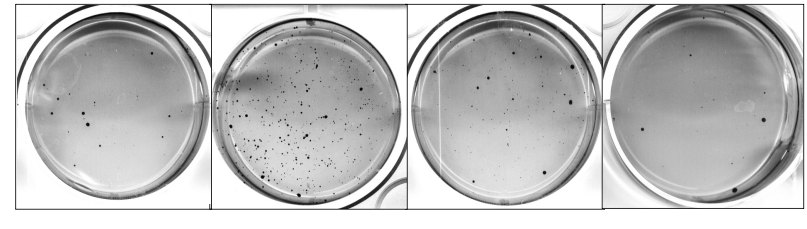

$1 \pm 0.12$

$2 \pm 0.14$

$1 \pm 0.07$

$0.1 \pm 0.03$

$C$
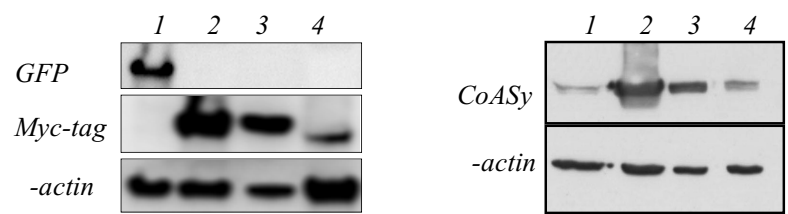

Fig. 1. Overexpression of CoASy protein in HEK293 cells promotes adherence independent proliferation and cell survival: $A$ - Overexpression of CoASy wt protein in HEK293 promotes cells survival. HEK293 cells stably overexpressing CoASy-Myc or EGFP proteins were serum starved for 48 hours. Cell viability was estimated by trypan blue dye excision assay and ratio of total/dead cells was calculated and plotted as fold change over EGFP expressing cells. Data are means $\pm \mathrm{s}$. d. of 5 experiments; $\mathrm{p} \leq 0.01$ (*against EGFP); $B$ - Overexpression of CoASy wt protein but not mutants CoASy H203A/G400A or $\triangle$ TMCoASy promotes adherence independent proliferation of HEK293. wtCoASy, H203A/G400A CoASy, or $\triangle \mathrm{TMCoASy}$ overxpressing cells were plated in agarose containing DMEM medium in triplicates as described in material and methods. Three weeks later, colonies were stained with MTT and counted using Quantity One Software (Bio-Rad), fold change over EGFP was calculated and data presented as means $\pm \mathrm{s}$. d. of 5 experiments; $C-$ Western blot analysis of established stable cell lines for expression of recombinant (top panel, anti-Myc) and overall, recombinant and endogenous CoASy protein (low panel, anti-CoASy): 1 - GFP; 2 CoASy-Myc; 3 - CoASy-Myc 203/400; 4 - $\Delta$ TMCoASy-Myc

from extracellular stimuli [18]. Appearance of inactivating mutations in the genes of the pathway suppressors (PTEN) or activating mutations in oncogenes (Ras, PI3K, Akt) is known to lead to malignant transformation of the cell [19]. We hypothesised that since we detected effects of CoASy protein on phosphorylation state of downstream targets of PI3K pathway [12], we could expect these changes to influence cells behaviour. To test this we estimated ability of cells with experimentally manipulated CoASy to survive and proliferate in conditions of growth factors and extracellular matrix anchorage deprivation.

To start with we have generated a set of stable cell lines which stably expressed Myc tag fused wild type CoA Synthase [1], $\Delta$ TM CoASy mutant with deleted mitochondria association signal [13] or catalytically inactive CoASy 203/400 mutant with His203Ala and Gly400Ala substitutions [11, 20]. Analysis of established stable cell lines with anti-Myc and anti-CoASy antibody is presented on Fig. 1, $C$.

We compared survival of HEK293 cells stably overexpressing CoASy or control cells expressing EGFP. To induce death, cells were cultured without serum for $48 \mathrm{hrs}$ and thereafter subjected to trypan blue exclusion assay to assess cells viability. For the both cell lines total and dead cells numbers were counted. Viability was calculated as a ratio between these values and presented as folds in comparison to EGFP overexpressing cells (Fig. 1, A). As a result, cells overexpressing CoASy were in average 1.7 folds more viable in comparison with control cells. It prompted us to conclude that increased level of CoASy protein has protective effect on cells in these conditions. One of the explanations of these results is up-regulation of survival signaling in CoASy overexpressing cells.

CoASy protein level affects anchorage-independent cell growth. As a further test, the semisolid agarose colonies forming assays was performed using the same stable cell lines. As a result we found that CoASy overexpression lead to increase in colonies number formed in agarose up to 2 folds in comparison to control cells (Fig. 1, B). Notably, similar results were obtained in other cell line (NIH3T3) (data not shown).

We also addressed the question whether observed increase in colonies number is dependent on catalytic activity of CoASy. Since CoA Synthase possesses two catalytic domains - phosphopantetheine adenylyltransferase (PPAT) and dephospho-CoA kinase (dPCoAK), we generated stable cell line expressing CoASy enzyme with amino acids substitutions H203A and G400A which result in inactivation of both catalytic activities of CoASy $[1,20]$. As it is seen from Fig. 1, $B$, expression of catalytically inactive CoASy has no effect on colonies formation. This result indicates importance of CoASy catalytic activity for the observed 
siRNA scrambled

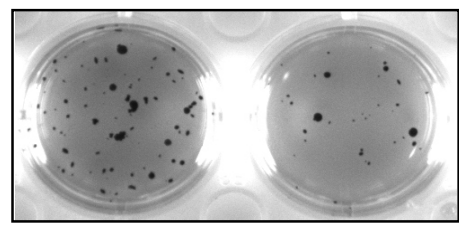

$1 \pm 0.16$

$0.55 \pm 0.12$
siRNA Scrambled CoASy

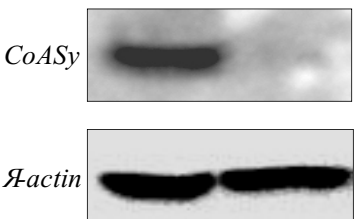

Fig. 2. siRNA mediated knockdown of endogenous CoASy level in HepG2 cells suppresses their ability to adherence independent proliferation. HepG2 cells were transfected with siRNA directed to CoASy or scrambled control as described in materials and methods. $48 \mathrm{hrs}$ posttransfection cells were plated in agarose as in Fig. 1, B, and efficiency of knock down was controlled by immunoblotting with anti-CoASy antibody (right panel). 17 days later colonies were stained with MTT and counted using Quantity One Software (Bio-Rad), fold change over scrambled control were calculated and data presented as means $\pm \mathrm{s}$. d. of 4 experiments

increase in cells ability to anchorage-independent proliferation.

Then, we were interested whether CoASy targeting to mitochondria is required for the colony forming phenotype. To estimate this we created stable cell line overexpressing CoASy containing mitochondria targeting sequence deletion, $\triangle \mathrm{TMCoASy}$ (29-563 aa). A subcellular localization and biochemical properties of this transiently expressed mutant protein was previously studied and described [13]. Because of deletion of the first 28 aa from the N-terminus CoASy mitochondrial localization is disrupted and protein accumulates in the cytoplasm. Surprisingly, we found that cells expressing $\triangle \mathrm{TMCoASy}$ protein formed significantly less colonies in semisolid agarose than cells expressing EGFP (Fig. 1, C). Consequently, expression of $\triangle \mathrm{TMCoASy}$ protein prevents the increase in colonies forming ability observed in wt CoASy overexpressing cells and dramatically suppresses ability of cells to adherence independent proliferation (Fig. 1, C). We conclude that both - CoASy activity and mitochondria localization are essential for promotion of anchorage independent cell growth.

Together, pro-survival, in serum depleted conditions, and anchorage-independence promoting effects of CoASy indicate this protein as a potential oncogene.

Next, we were interested to confirm observed results using alternative approach. We knocked down the expression of endogenous CoASy in HepG2 cell line that expresses malignant phenotype. In this case
siRNA mediated selective knock down of CoASy led to significant reduction of a number of colonies formed in agarose medium in comparison to cells which were transfected with scrambled siRNA (Fig. 2, left panel). The effective knock down of CoASy expression was confirmed by immunoblot with anti-CoASy antibody (Fig. 2, right panel).

CoASy is not unique metabolic enzyme changes in expression or activity of which have impact on cellular signalling. Two recent studies demonstrate that an embryonic- and cancer-cell-specific isoform of the glycolitic enzyme pyruvate kinase M2 (PKM2) is regulated by binding to phospho-tyrosine motifs of signalling proteins and promotes increased cell growth and tumour development [21, 22].

Up-regulation of expression and activity of lipogenic enzymes which mediate de novo fatty acids synthesis is a widely reported event in tumour cells in a variety of human cancers [23]. Well characterized examples include fatty acid synthase (FAS) [23, 24, 25], acetyl-CoA carboxylase $\alpha[23,25,26]$ and ATP citrate lyase (ACL) [23, 27]. Interestingly, it was demonstrated that pharmacological or siRNA mediated inhibition of FAS blocks cell proliferation, induces apoptosis of cancer cells cultured in vitro and retards the growth of tumors in murine xenograft models. These findings have confirmed the potential of FAS as a major target for antineoplastic intervention [23]. Notably, targeting of other lipogenic enzymes led to the similar effects demonstrating that lipid synthesis per se is important for survival of cancer cell [23, 27, 28]. The reasons of why it is so remain poorly understood. The simplest explanation is requirement of actively proliferating cells in lipids as biosynthetic material. In contrast to lipogenic enzymes, CoA Synthase is ubiquitously expressed and we did not detect significant changes in its expression on the protein level in at least tested cancer cell lines (O. B., I. N. and G. P. unpublished observations). However, elevated levels of CoASy mRNA were reported for cancer cell lines in comparison to normal tissues [2].

Similar to our observations, several effects of FAS on cellular signalling have been reported. One of them describes requirement of FAS activity for Akt1 activation. Moreover, other report that FAS overexpression leads to a dramatic increase in the number of 
phospho-tyrosine-containing proteins, including hyperphosphorylation of epidermal growth factor receptors HER1/HER2 [29, 30]. The mechanisms underlying these effects are not known. Nevertheless there are several hypothetical explanations. It is known that activated de novo lipogenesis change lipid composition of cell membranes, promotes protein acylation, affects the redox status in cancer cells and also may affect gene expression [23]. All these effects potentially can influence signal transduction in different pathways and in PI3K pathway in particular. Coenzyme A is an essential cofactor for lipid and energetic metabolism and its availability may directly influence de novo lipogenesis, TCA turnover and glycolisis all of which change dramatically in cancer cells.

Conclusions. The observed effects of CoASy expression, activity and subcellular localization on anchorage independent growth and viability of mammalian cells cultured in vitro prompted us to do following conclusions. Increased levels of CoASy protein have protective effect on cells in conditions of growth factors deprivation and also support anchorage independent growth. We hypothesize that these effects mediated by up-regulation of survival signaling in these cells. CoASy activity and mitochondria localization are essential for promotion of anchorage independent cell growth. Knock down of CoASy expression in cancer cell line (HepG2) lead to the dramatic decrease in ability of these cells to form colonies in semisolid agarose. Notably, this ability is one of the hallmarks of cellular malignant transformation.

Acknowledgements. Dr. Ivan Nemazanyy was supported by Wood-Whelan Research Fellowship; Oksana Breus was supported by EMBO Short-Term fellowship. We thank Nadeem Shaikh for critical reading of the manuscript and helpful suggestions.

О. С. Бреус, І. О. Немазаний, І. Т. Гут, В. В. Філоненко, Г. Г. Панасюк

КоА синтаза впливає на незалежний від контактів 3 позаклітинним матриксом ріст та виживання клітин ссавців за умов in vitro

Резюме

Мета. Оиінити вплив рівня експресї, каталітичної активності та субклітинної локалізаиії КоА синтази на незалежний від контактів із позаклітинним матриксом ріст та виживання клітин у культурі in vitro. Методи. Вивчали здатність клі- тин до формування колоній в напіврідкій агарозі та виживання за відсутності ростових факторів. Створено стабільні клітинні лінії на основі клітин НЕК293, щзо надекспресують КоА синтазу дикого типу, а також мутантні - каталітично неактивну форму, або КоА синтазу із делетованою послідовністю, щзо відповідає за асоиіацію з мітохондріями. Досліджували також ефекти опосередкованого міРНК зниження ендогенного рівня КоА синтази на раковий фенотип клітин НерG2. Результати. Зміни в експресії КоА синтази впливають на незалежний від прикріплення ріст і виживання клітин ссавиів. Каталітична активність КоА синтази, а також асоиіація ї̈ з мітохондріями виявилися необхідними для опосередкування спостережених ефектів. Висновки. Представлені дані вказують на те, щзо КоА синтаза чинить позитивний вплив на сигнальні шляхи клітини, та виявляють невідомий раніше функціональний зв'язок між передаванням сигналів в клітині та метаболізмом.

Ключові слова: КоА синтаза, коензим А, незалежний від прикріплення ріст, життєздатність клітин.

О. С. Бреус, И. А. Немазаный, И. Т. Гут, В. В. Филоненко, Г. Г. Панасюк

КоА синтаза влияет на независимый от контактов с внеклеточным матриксом рост и выживание клеток млекопитающих в условиях in vitro

Резюме

Цель. Оценка влияния уровня экспрессии, каталитической активности и субклеточной локализации КоА синтазы на независимый от контактов с внеклеточным матриксом рост $u$ выживание клеток в культуре in vitro. Методы. В работе оиенивали способность клеток формировать колонии в полужидкой агарозе и выживать в отсутствии ростовых факторов. Были созданы стабильные клеточные линии на основе клеток HEK293, которые надэкспресировали КоА синтазу дикого типа, а также мутантные - каталитически неактивную форму, либо КоА синтазу с делетированой последовательностью, отвечающей за ассоциацию с митохондриями. Исследовались также эффекты миРНК опосредованного снижения эндогенного уровня КоА синтазы на раковый фенотип клеток Нер $G 2$. Результаты. Изменения в уровне экспрессии КоА синтазы влияли на независимый от прикрепления рост и выживание клеток млекопитающих. Каталитическая активность КоА синтазы, а также ассочиаџия ее с митохондриями оказались необходимыми для опосредования наблюдаемых эффектов. Выводы. Представленные данные указывают, что КоА синтаза позитивно влияет на активность сигнальных путей в клетках млекопитающих, а также вскрывают неизвестную ранее функииональную связь между передачей сигналов в клетке и метаболизмом.

Ключевые слова: КоА синтаза, кофермент А, независимый от прикрепления рост, жизнеспособность клеток.

\section{REFERENCES}

1. Zhyvoloup A., Nemazanyy I., Babich A., Panasyuk G., Pobigailo N., Vudmaska M., Naidenov V., Kukharenko O., Palchevskii S., Savinska L., Ovcharenko G., Verdier F., Valovka 
T., Fenton T., Rebholz H., Wang M.L., Shepherd P., Matsuka G., Filonenko V., Gout I. T. Molecular cloning of CoA Synthase. The missing link in CoA biosynthesis // J. Biol. Chem.2002.-277, N 25.-P. 22107-22110.

2. Daugherty M., Polanuyer B., Farrell M., Scholle M., Lykidis $A$., de Crecy-Lagard V., Osterman A. Complete reconstitution of the human coenzyme A biosynthetic pathway via comparative genomics // J. Biol. Chem.-2002.-2277, N 24.P. 21431-2139.

3. Abiko Y. Metabolism of coenzyme A // In metabolic pathways / Ed. D. Greenberg.-New York: Acad. press, 1975.-P. 25-50. 4. Leonardi R., Zhang Y. M., Rock C. O., Jackowski S. Coenzyme A: back in action // Progr. Lipid. Res.- 2005.-44, N 23.-P. 125-153.

5. Black P. N., Faergeman N. J., DiRusso C. C. Long-chain acyl-CoA-dependent regulation of gene expression in bacteria, yeast and mammals // J. Nutr.-2000.-130, N 2S suppl. P.305S-309S.

6. Takahashi H., McCaffery J. M., Irizarry R. A., Boeke J. D. Nucleocytosolic acetyl-coenzyme a synthetase is required for histone acetylation and global transcription // Mol. Cell.2006.-23, N 2.-P. 207-217.

7. Resh M. D. Regulation of cellular signalling by fatty acid acylation and prenylation of signal transduction proteins // Cell. Signal.-1996.-8, N 6.-P. 403-412.

8. Linder M. E., Deschenes, R. J. Palmitoylation: policing protein stability and traffic // Nat. Rev. Mol. Cell. Biol.-2007.-8, N 1.-P.874-884.

9. Pfanner N., Orci L., Glick B. S., Amherdt M., Arden S. R., Malhotra V., Rothman J. E. Fatty acyl-coenzyme A is required for budding of transport vesicles from Golgi cisternae // Cell.-1989.-59, N 1.-P. 95-102.

10. Bosveld F., Rana A., van der Wouden P. E., Lemstra W., Ritsema M., Kampinga H. H., Sibon O. C. De novo CoA biosynthesis is required to maintain DNA integrity during development of the Drosophila nervous system // Hum. Mol. Genet.-2008.-17, N 13.-P. 2058-2069.

11. Nemazanyy I., Panasyuk G., Zhyvoloup A., Panayotou G., Gout I. T., Filonenko V. V. Specific interaction between S6K1 and CoA Synthase: a potential link between the mTOR/S6K pathway, CoA biosynthesis and energy metabolism // FEBS Lett.-2004.-578, N 3.-P. 357-362.

12. Breus O., Panasyuk G., Gout I. T., Filonenko V., Nemazanyy I. CoA Synthase is in complex with p85alphaPI3K and affects PI3K signaling pathway // Biochem. and Biophys. Res. Communs.-2009.-385, N 4.-P. 581-585.

13. Zhyvoloup A., Nemazanyy I., Panasyuk G., Valovka T., Fenton T., Rebholz H., Wang M. L., Foxon R., Lyzogubov V., Usenko V., Kyyamova R., Gorbenko O., Matsuka G., Filonenko V., Gout I. T. Subcellular localization and regulation of coenzyme A synthase // J. Biol. Chem.-2003.-278, N 50.P. 50316-50321.

14. Frisch S. M., Francis H. Disruption of epithelial cell-matrix interactions induces apoptosis // J. Cell. Biol.-1994.-124, N 4.-P. 619-626.

15. Chiarugi $P$. From anchorage dependent proliferation to survival: lessons from redox Signalling // IUBMB Life.-2008.60.-P. 301-307.

16. Nakamura K., Sakaue H., Nishizawa A., Matsuki Y., Gomi H., Watanabe E., Hiramatsua R., Tamamori-Adachi M., Kitajima S., Noda T., Ogawa W. , Kasuga M. PDK1 regulates cell proliferation and cell cycle progression through control of cyclin D1 and p27Kip1 expression // J. Biol. Chem.2008.-283, N 25.-P. 17702-17711.

17. Vander Heiden M. G., Plas D. R., Rathmell J. C., Fox C. J., Harris M. H., Thompson C. B. Growth factors can influence cell growth and survival through effects on glucose metabolism // Mol. Cell. Biol.-2001.-21, N 17.-P. 58995912.

18. Duronio $V$. The life of a cell: apoptosis regulation by the PI3K/PKB pathway // Biochem. J.-2008.-415.-P. 333-344.

19. Yuan T. L., Cantley L. C. PI3K pathway alterations in cancer: variations on a theme // Oncogene-2008.-27, N 41.-P. 54975510.

20. Veitch D. P., Gilham D., Cornell R. B. The role of histidine residues in the HXGH site of CTP: phosphocholine cytidylyltransferase in CTP binding and catalysis // Eur. J. Biochem.1998.-255, N 1.-P. 227-234.

21. Christofk H. R., Vander Heiden M. G., Wu N., Asara J. M., Cantley L. C. Pyruvate kinase M2 is a phosphotyrosinebinding protein // Nature.-2008.-452, N 7184.-P. 181-186.

22. Christofk H. R., Vander Heiden M. G., Harris M. H., Ramanathan A., Gerszten R. E., Wei R., Fleming M. D., Schreiber $S$. L., Cantley L. C. The M2 splice isoform of pyruvate kinase is important for cancer metabolism and tumour growth // Nature-2008.-452, N 7184.-P. 230-233.

23. Swinnen J. V., Brusselmans K., Verhoeven G. Increased lipogenesis in cancer cells: new players, novel targets // Curr. Opin. Clin. Nutr. Metab. Care.-2006.-9, N 4.-P. 358-365.

24. Menendez J. A., Lupu R. Fatty acid synthase and the lipogenic phenotype in cancer pathogenesis // Nat. Rev. Cancer.2007.-7, N 10.-P. 763-777.

25. Yoon S., Lee M. Y., Park S. W., Moon J. S., Koh Y. K., Ahn Y. H., Park B. W., Kim K. S. Up-regulation of acetyl-CoA carboxylase alpha and fatty acid synthase by human epidermal growth factor receptor 2 at the translational level in breast cancer cells // J. Biol. Chem.-2007.-282, N 36.P. 26122-26131.

26. Brunet J., Vazquez-Martin A., Colomer R., Graca-Suarez B., Martin-Castillo B., Menendez J. A. BRCA1 and acetyl-CoA carboxylase: the metabolic syndrome of breast cancer // Mol. Carcinog.-2008.-47, N 2.-P. 157-163.

27. De Schrijver E., Brusselmans K., Heyns W., Verhoeven, G., Swinnen $J . V$. RNA interference-mediated silencing of the fatty acid synthase gene attenuates growth and induces morphological changes and apoptosis of $\mathrm{LNCaP}$ prostate cancer cells // Cancer Res.-2003.-63, N 13.-P. 3799-3804.

28. Brusselmans K., De Schrijver E., Verhoeven G., Swinnen J. $V$. RNA interference-mediated silencing of the acetyl-CoAcarboxylase-alpha gene induces growth inhibition and apoptosis of prostate cancer cells // Cancer Res.-2005.-65, N 15.-P. 6719-6725.

29. Wang H. Q., Altomare D. A., Skele K. L., Poulikakos P. I., Kuhajda F. P., Di Cristofano A., Testa J. R. Positive feedback regulation between AKT activation and fatty acid synthase expression in ovarian carcinoma cells // Oncogene.-2005.24.-P. 3574-3582.

30. Vazquez-Martin A., Colomer R., Brunet J., Lupu R., Menen$\operatorname{dez} J$. A. Overexpression of fatty acid synthase gene activates HER1/HER2 tyrosine kinase receptors in human breast epithelial cells // Cell Prolif.-2008.-41, N 1.-P. 59-85.

УДК 577.2:577.27

Надійшла до редакції 15.05.09 